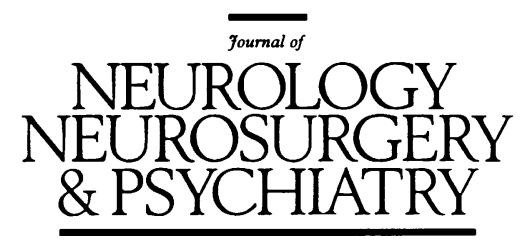

\title{
Editorial
}

\section{Molecular pathology of Alzheimer's disease}

The impact of molecular biology on neurological disease in the last five years has been dramatic, albeit anticipated, and Alzheimer's disease is no exception. However, the advances in Alzheimer's disease are remarkable for the accompanying change in attitude from the view that it is an inexorable degenerative condition which overlaps with ageing, to the view that it is a disease which may have an identifiable, and by inference potentially treatable, molecular pathology. These advances awaited the biochemical studies on the two key neuropathological features of Alzheimer's disease, namely neurofibrillary tangles and senile plaques.

Neurofibrillary tangles are perikaryal silver-stained inclusions found particularly in pyramidal cortical neurons and the diffuse subcortical projection system. Electron microscopy shows neurofibrillary tangles to consist of paired helical filaments ${ }^{1}$ and recent isolation and purification of the central core of the paired helical filament permitted partial amino acid sequencing and subsequent identification of the encoding gene. This was found to be the microtubule associated protein tau. ${ }^{23}$ The abnormality that leads to the aggregation of tau to form neurofibrillary tangles may be a consequence of abnormal hyperphosphorylation, ${ }^{4}$ although it is still not clear whether this molecular event is merely a late consequence of neuronal metabolic disturbance, since neurofibrillary tangles can be found in a variety of diseases. The same approach of protein sequencing and gene cloning has been applied to the other neuropathological marker, the senile plaque. This consists of a rim of dystrophic neurites around a central core of an amyloid protein, classified on the basis of insolubility, Congo red staining with birefringence and fibril formation, a feature shared with other amyloid proteins and believed to be related to a cross linked beta pleated structure. The insolubility of the senile plaque amyloid delayed chemical isolation, but once achieved it was shown to be a 39 to 42 amino acid protein referred to as amyloid $\beta$-protein, A4 protein or $\beta A 4$ peptide. This was shown to be the same protein that is deposited in blood vessels to cause the congophilic angiopathy of Alzheimer's disease. ${ }^{5-7}$ From the primary amino acid sequence the cDNA clone was isolated and was shown to encode for a much larger 770 amino acid protein, of which the $\beta A 4$ peptide was only a small component. ${ }^{8}$ This amyloid precursor protein (APP) molecule is a transmembrane protein of which the majority is extracellular. The $\beta A 4$ component is partially embedded within the membrane (fig). There are at least six different APP transcripts due to differential splicing, of which four contain the $\beta A 4$ moiety. The three major transcripts, APP 695, 751 and 770, all contain the $\beta$ A4 sequence and APP 751 and 770 also contain a conserved sequence found in the Kunitz family of protease inhibitors, the best-studied member of which is bovine pancreatic trypsin inhibitor or aprotinin. Cell proliferation and differentiation require a series of surface-related proteolytic events which may be regulated by such protease inhibitors. ${ }^{9-11}$ The inclusion of a Kunitz domain in the APP molecule suggests a physiological role for the protein in protease activity regulation and certainly one secreted form of APP, resulting from cleavage of the extra cellular component, is identical to the protease inhibitor, protease nexin-II. ${ }^{12}{ }^{13}$ APP 770 is the main transcript in most tissues, but in brain APP 695, which lacks the protease inhibitor domain, predominates.

The physiological role of APP in the brain is unclear, but currently the subject of intense research. It is synthesised in the cell bodies and then undergoes fast anterograde axonal transport to the synaptic endings where it is colocalised with synaptophysin ${ }^{14}$ and is believed to be involved in the maintenance of synaptic contact. ${ }^{15}$ The homology to protease nexin-II also suggests a role as a growth regulating factor..$^{12}$ Much speculation, however, has centred on the increase in APP expression in response to a variety of neuronal stresses ${ }^{16-18}$ which include head injury. ${ }^{19}$ This response is mediated by interleukin I and so is similar to the stress response of the heat shock protein family, a set of evolutionary-conserved proteins which are expressed in response to cell stress. ${ }^{20}$

If amyloid deposition is a key process in Alzheimer's disease then clearly $\beta \mathrm{A} 4$ has to be released via processing of the APP molecule. There are two main pathways. The first is the so called secretase pathway which results in a cleavage near to the membrane surface before Leucine $688^{21}$ and releases the extracellular component; the secretase enzyme appears to recognise an $a$-helix confirmation some $12-13$ residues from the membrane. ${ }^{22}$ The second pathway, the endosomal-lysosomal pathway, involves internalisation of the APP molecule and subsequent degradation which produces potentially amyloidogenic carboxy-terminal fragments, some of which contain intact the $\beta \mathrm{A} 4$ sequence. ${ }^{23-25}$ Moreover, soluble $\beta \mathrm{A} 4$ peptide, as opposed to fibrillary amyloid, can be produced by healthy cells in culture and can be measured in human CSF. ${ }^{26} 27$

Much of the intense research into the structure and function of APP has been driven by the discovery of mutations in the APP gene associated with familial Alzheimer's disease (FAD). The realisation of the hereditary significance of Alzheimer's disease has been rela- 


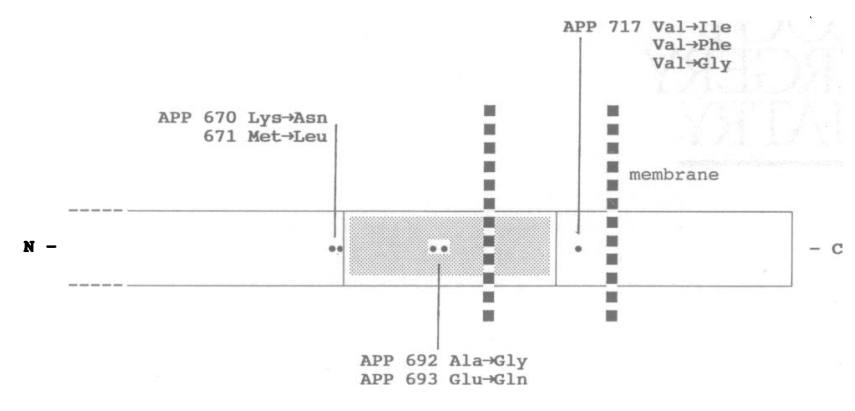

Shaded area indicates the $\beta \mathrm{A} 4$ amyloid domain.

Figure Amyloid precursor protein mutations

tively recent (for review see Rossor, $1992^{28}$ ). In the last 10-15 years, however, a number of large autosomal dominantly inherited Alzheimer's disease pedigrees have been described. ${ }^{29}$ Such extensive pedigrees are ideal for linkage studies and these initially concentrated on chromosome 21 markers since trisomy 21 Down's syndrome is associated with the development of Alzheimer histopathology. Linkage to markers on the proximal long arm of chromosome 21 was reported in $1987,{ }^{30}$ the same year that the APP gene was identified. ${ }^{8}$ Clearly APP was a candidate gene, but was excluded in a number of families; ${ }^{31}$ this exclusion is now known to be due to the genetic heterogeneity of the disease. ${ }^{32}$

Careful screening of other families, however, established the first mutation associated with Alzheimer's disease, a single point mutation at APP 717 resulting in a Valine $\rightarrow$ Isoleucine substitution ${ }^{33}$ and subsequently two other mutations at the same site have been reported, APP 717 Valine $\rightarrow$ Phenylalanine $^{34}$ and APP 717 Valine $\rightarrow$ Glycine. ${ }^{35}$ More recently a double mutation at APP 670/671 resulting in Lysine $\rightarrow$ Asparagine and Methionine $\rightarrow$ Leucine substitutions has been found in two probably related, Swedish families with $\mathrm{FAD}^{36}$ (see table). Other mutations in the APP molecule had been reported previously in association with congophilic angiopathy. APP $693 \mathrm{Glu} \rightarrow \mathrm{Gln}$ is associated with hereditary cerebral haemorrhage with amyloidosis-Dutch type,$^{37}$ a disease with recurrent cortical haemorrhage and prominent congophilic angiopathy, parenchymal $\beta \mathrm{A} 4$ deposits, but no plaques or tangles. A mutation at the adjacent site, APP $692 \mathrm{Ala} \rightarrow$ Gly has also been reported in a Dutch family in whom some members develop congophilic angiopathy with haemorrhage and others a progressive cognitive decline. ${ }^{38}$ It is notable that the APP mutations at $670 / 671$ and APP 717 which are associated with Alzheimer's disease, are at the $\mathrm{N}$ - and C-terminus respectively of the $\beta \mathrm{A} 4$ domain $^{39}$ whereas those associat-

Table Genetic mutations associated with Alzheimer's disease

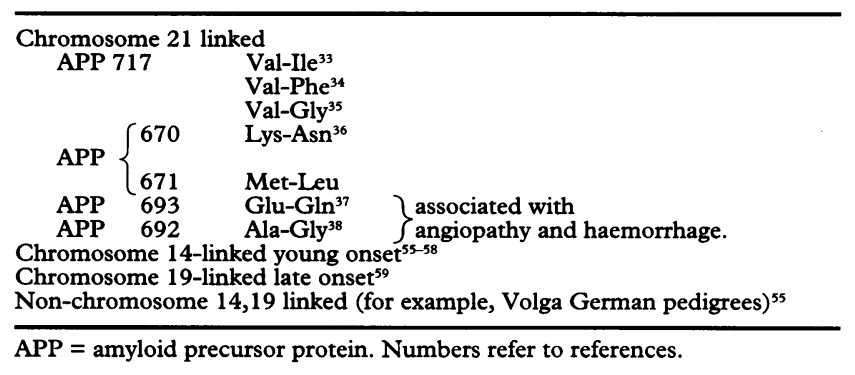

ed with congophilic angiopathy at APP 692 and 693 are near to the secretase cleavage site (fig). A direct link between an APP mutation and $\beta A 4$ deposition has been established in cultured cells which have been transfected with APP 670/671 mutation cDNA and which produce $6-8$-fold more $\beta$ A4 peptide than cells expressing normal APP. 40

If it is accepted that APP mutations in these families cause the disease then amyloid deposition from the APP molecule is seen to be the essential pathological process and the "amyloid cascade hypothesis" has been generalised to other familial and sporadic cases. ${ }^{41}$ Although APP mismetabolism would appear to be established as the cause in these few families, the generalisation of this hypothesis remains speculative. A number of questions remain unanswered, not the least of which is how amyloid deposition itself leads to cell death and tangle formation. $\beta \mathrm{A} 4$ peptide has been reported to be directly toxic to neurons in culture ${ }^{4243}$ and APP cDNA-transfected P19 cells show spontaneous degeneration when induced to transform into post-mitotic neurons. ${ }^{44}$ Alternatively, there is evidence that $\beta \mathrm{A} 4$ peptide may have an indirect, rather than direct toxic effect, to enhance glutamate toxicity via disruption of internal calcium homeostasis. This would also provide an explanation for tangle formation since tau hyperphosphorylation is calcium dependent. ${ }^{46}$ However, the changes which would render normal soluble $\beta-\mathrm{A} 4$ peptide toxic are at present unknown. ${ }^{26}$

Where do these advances in APP biochemistry and molecular genetics leave the clinician? How important are APP mutation families and what is the relationship to FAD and sporadic Alzheimer's disease in general? Firstly, APP mutation families appear to be extremely rare; to date eight APP $717 \mathrm{Val} \rightarrow \mathrm{Ile}$, one Val $\rightarrow$ Gly, one $\mathrm{Val} \rightarrow$ Phe and two probably related APP $670-671$ families have been reported. This represents less than $5 \%$ of the young onset FAD cases. In general, the families are similar to other cases of FAD and sporadic Alzheimer's disease with early memory impairment and a generalised cognitive decline. ${ }^{28}$ The APP $717 \mathrm{Val} \rightarrow$ Ile families share with other FAD pedigrees features of prominent myoclonus ${ }^{47}$ and in the original APP $717 \mathrm{Val}$ $\rightarrow$ Ile pedigree prominent extra pyramidal features were seen in some cases, which could be related to the presence of Lewy bodies in a single necropsied case. ${ }^{48}$ Only single APP $717 \mathrm{Val} \rightarrow \mathrm{Phe}^{49}$ and APP $717 \mathrm{Val} \rightarrow$ Gly families have been reported. These show similar features to the APP $717 \mathrm{Val} \rightarrow$ Ile cases, but seizures in the APP $717 \mathrm{Val} \rightarrow$ Gly pedigree were an additional prominent clinical feature. ${ }^{50}$ Of interest is the fact that all APP mutation families have a broadly similar age of onset at around 50 years. Neuropathologically they have identical features of plaques and tangles and the cytoskeletal pathology with hyperphosphorylated tau is the same as that of sporadic Alzheimer's disease. ${ }^{4851}$ One unusual feature of the index APP $717 \mathrm{Val} \rightarrow$ Ile family was the presence of Lewy bodies ${ }^{48}$ but this has not been a consistent feature of this particular mutation.

Although the APP mutation families are rare, demonstration of the mutation does allow a definitive diagnosis in life without need for biopsy and, together with the prion dementia mutations ${ }^{52}$ justifies, screening in all young onset dementias with a family history. Moreover, this now allows predictive testing as with the prion dementias. ${ }^{53}$ The constant age at onset in APP mutation FAD suggests that a considerable degree of accuracy of predictive testing might be possible. Considerable caution however, needs to be exercised, since although the mutations appear to be fully penetrant, the ascertainment 
of families for linkage analysis tends to self select such pedigrees. A clinical consortium is now being formed to establish guidelines for the interpretation of these mutations in predictive testing and counselling.

What of the other FAD cases? It is clear from the linkage data that FAD is genetically heterogeneous. ${ }^{32}$ Clinical heterogeneity in FAD has been assumed to reflect the underlying genetic heterogeneity. ${ }^{54}$ Recently chromosome 14 linkage has been reported in a number of young onset cases $^{55-58}$ which show an earlier age at onset than those families with APP mutations. There are a number of candidate genes in this region of chromosome 14; the gene for $a-1$ antichymotrypsin which is found in association with senile plaques has been excluded ${ }^{56}$ but the gene for heat shock protein (HSP A2) is another interesting candidate because it shares stress induced up regulation with APP. It remains to be seen whether mutations on chromosome 14 will interact with APP metabolism and if so at what stage. The study by Schellenberg $e t a \bar{l}^{5}$ suggests that a substantial proportion of early onset cases can be explained by chromosome 14 linkage, although other cases are not linked, for example, the Volga German pedigrees. These are an ethnic group of Germans who emigrated to Russia in the late 18th century and subsequently to the USA and have a high prevalence of FAD. ${ }^{55}$ There is also the problem of late onset familial Alzheimer's disease, which is considerably more difficult to analyse by molecular genetics, but in which chromosome 19 linkage has been reported..$^{59}$

Increasingly, the term Alzheimer's disease can be seen to be a rubric to cover a clinical and neuropathological entity which may be the end stage of many different disease processes and may or may not have amyloid deposition as the final common pathway. Alzheimer's disease might thus be considered to resemble cirrhosis of the liver, a clinicopathological entity with a variety of causes. As with cirrhosis of the liver it also puts Alzheimer's disease rightfully into the category of metabolic disorders, with the optimism for treatment and prevention that is associated with such diseases.

The National Hospital for Neurology and Neurosurgery, Queen Square, London WC1 $3 B G$

and St Mary's Hospital, Praed Street, London W2 1NY, UK

1 Kidd M. Paired helical filaments in electron microscopy of Alzheimer's disease Nature 1963;197:192-3.

2 Wischik CM, Novak M, Thogersen HC, et al. Isolation of a fragment of tau derived from the core of the paired helical filament of Alzheimer disease. Proc Natl Acad Sci USA 1988;85:4506-10.

3 Goedert M, Wischik CM, Crowther RA, Walker JE, Klug A. Cloning and sequencing of the $\mathrm{cDNA}$ encoding a core protein of the paired helical sequencing of the cDNA encoding a core protein of the paired helical
filament of Alzheimer disease: identification of the microtubule-associfilament of Alzheimer disease: identification of the micro

4 Lee VM-Y, Balin BJ, Otvos L Jr, Trojanowski JQ. A68: a major subunit of paired helical filaments and derivatized forms of normal tau. Science 1991;251:675-8.

5 Glenner GG, Wong CW. Alzheimer's disease: initial report of the purification and characterization of a novel cerebrovascular amyloid protein. Biochem Biophys Res Commun 1984;120:885-90.

6 Masters CL, Simms G, Weinmann NA, et al. Amyloid plaque core protein in Alzheimer's disease and Down syndrome. Proc Natl Acad Sci USA 1985;82:4245-9.

7 Selkoe DJ, Abraham CR, Podlisny MB, Duffy LK. Isolation of LowMolecular-Weight Proteins from Amyloid Plaque Fibers in Alzheimer's disease. $\mathcal{F}$ Neurochemistry 1986;46:1820-34.

8 Kang J, Lemaire H-G, Unterbeck A, et al. The precursor of Alzheimer's disease amyloid A4 protein resembles a cell-surface receptor. Nature 1987;325:733-6.

9 Kitaguchi N, Takahashi Y, Tokushima Y, Shiojiri S, Ito H. Novel precursor of Alzheimer's disease amyloid protein shows protease inhibitory activity. Nature 1988;331:530-2.

10 Ponte P, Gonzalez-DeWhitt P, Schilling J, et al. A new A4 amyloid mRNA contains a domain homologous to serine proteinase inhibitors. Nature 1988;331:525-7.

11 Tanzi RE, McClatchey AI, Lamperti ED, Villa-Komaroff LT, Gusella JF, Neve RL. Protease inhibitor domain encoded by an amyloid protein precursor mRNA associated with Alzheimer's disease. Nature 1988;331:528-30.

12 Oltersdorf T, Fritz LC, Schenk DB, et al. The secreted form of Alzheimer's disease with the Kunitz domain is protease nexin-II. Nature 1989;341:144-7.
13 Van Nostrand WE, Schmaier AH, Farrow JS, Cunningham DD. Protease nexin-II (amyloid beta-protein precursor): a platelet alpha-granule protein. Science 1990;248:745-8.

14 Koo EH, Sisodia SS, Archer DA, et al. Precursor of amyloid protein in Alzheimer's disease undergoes fast anterograde axonal transport. Proc Natl Acad Sci USA 1990;87:1561-5.

15 Schubert $W$, Prior R, Weidemann A, et al. Localization of Alzheimer $\beta A 4$ amyloid precursor protein at central and peripheral synaptic sites. Brain Res 1991;563:184-94.

16 Abe K, St George-Hyslop PH, Tanzi RE, Kogure K. Induction of amyloid precursor protein mRNA after heat shock in cultured human lymphoblastoid cells. Neurosci Lett 1991;125:169-71.

17 Abe K, Tanzi RE, Kogure K. Selective induction of Kunitz-type protease inhibitor domain-containing amyloid precursor protein mRNA after persistent focal ischemia in rat cerebral cortex. Neurosci Lett 1991;125. $172-4$.

18 Kawarabayashi $T$, Shoji $M$, Harigaya $Y$, Yamaguchi $H$, Hirai $S$. Expression of APP in the early stage of brain damage. Brain Res 1991;563:334-8.

19 Roberts G, Gentleman S, Lynch A, Graham D. BA4 amyloid protein deposition in the brain after head trauma. Lancet 1991;338:1422-3.

20 Goldgaber D, Harris HW, HLA T, et al. Interleukin 1 regulates synthesis of amyloid $\beta$-protein precursor mRNA in human endothelial cells. Proc Natl Acad Sci USA 1989;86:7606-10.

21 Anderson JP, Esch FS, Keim PS, Sambamurti K, Leiberburgh I, Robakis NK. Exact cleavage site of Alzheimer amyloid precursor in neuronal NK. Exact cleavage site of Alzheimer amylo

22 Sisodia SS. $\beta$-Amyloid precursor protein cleavage by a membrane-bound protease. Proc Natl Acad Sci USA 1992;89:6075-9.

23 Estus S, Golde TE, Kunishita T, et al. Potentially amyloidogenic, carboxyl-terminal derivatives of the amyloid protein precursor. Science 1992;225:726-8.

24 Golde TE, Estus S, Younkin LE, Selkoe DJ, Younkin SG. Processing of the amyloid protein precursor to potentially amyloidogenic derivatives. Science 1992;255:728-30.

25 Haas C, Koo EH, Mellon A, Hung AY, Selkoe DJ. Targeting of cell surface $\beta$-amyloid precursor protein to lysosomes: alternative processing into amyloid-bearing fragments. Nature 1992;357:500-3.

26 Haas C, Schlossmacher MG, Hung AY, et al. Amyloid $\beta$-peptide is produced by cultured cells during normal metabolism. Nature 1992b;359: $322-5$.

27 Seubert P, Vigo-Pelfrey C, Esch F, et al. Isolation and quantification of soluble Alzheimer's $\beta$-peptide from biological fluids. Nature 1992;359: 325-7.

28 Rossor MN. Familial Alzheimer's disease. In: Rossor MN, ed. Unusual dementias 3rd ed. London: Baillière Tindall, 1992;517-34.

29 Nee L, Polinsky R, Eldridge R, et al. A family with histologically confirmed Alzheimer's disease. Arch Neurol 1983;40:203-8.

30 St George-Hyslop P, Tanzi R, Polinsky R, et al. The genetic defect causing familial Alzheimer's disease maps on chromosome 21. Science 1987;235:885-90.

31 Van Broekhoven C, Genthe AM, Vandenberghe A, et al. Failure of familial Alzheimer's disease to segregate with the A4-amyloid gene in several European families. Nature 1987;329:153-5.

32 St George-Hyslop PH, Haines JL, Farrer LA, et al. Genetic linkage studies suggest that Alzheimer's disease is not a single homogeneous disorder. Nature 1990;347:194-7.

33 Goate A, Chartier-Harlin MC, Mullan M, et al. Segregation of a missense mutation in the amyloid precursor protein gene with familial mutation in the amyloid precursor prot
Alzheimer's disease. Nature 1991;349:704-6.

34 Murrell J, Farlow M, Ghetti B, Benson M. A mutation in the amyloid precursor protein associated with hereditary Alzheimer's disease. Science 1991;254:97-9.

35 Chartier-Harlin MC, Crawford F, Houlden H, et al. Early-onset Alzheimer's disease caused by mutations at codon 717 of the beta-amyloid precursor protein gene. Nature 1991;353:844-6.

36 Mullan M, Crawford F, Axelman K, et al. A pathogenic mutation for probable Alzheimer's disease in the APP gene at the N-terminus of $\beta$ amyloid. Nature Genetics 1992;1:345-7.

37 Levy E, Carmen MD, Fernandez-Madrid IJ, et al. Mutation of the Alzheimer's disease amyloid gene in hereditary cerebral haemorrhage, Dutch type. Science 1990;248:1124-6.

38 Hendriks L, van Duijn CM, Cras P, et al. Presenile dementia and cerebral haemorrhage linked to a mutation at codon 692 of the $\beta$-amyloid prehaemorrhage linked to a mutation at codon 692 of
cusor protein gene. Nature Genetics 1992;1:218-21.

39 Hardy J. Framing $\beta$-amyloid. Nature Genetics 1992;1:233-4.

40 Citron M, Oltersdorf T, Haass C, et al. Mutation of the $\beta$-amyloid precursor protein in familial Alzheimer's disease increases $\beta$-protein production. Nature 1992;360:672-4

41 Hardy J, Higgins GA. Alzheimer's disease: the amyloid cascade hypothesis. Science 1992;256:184-5.

42 Yankner BA, Duffy LK, Kirschner DA. Neurotrophic and neurotoxic effects of amyloid $\beta$ protein: reversal by tachykinin neuropeptides. Science 1990;250:279-82.

43 Kowall NW, Beal MF, Busciglio J, Duffy LK, Yankner BA. An in vivo model for the neurodegenerative effects of $\beta$ amyloid and protection by substance P. Proc Natl Acad Sci USA 1991;88:7247-51.

44 Yoshikawa K, Aizawa T, Hayashi Y. Degeneration in vitro of post-mitotic neurons overexpressing the Alzheimer amyloid protein precursor. Nature 1992;359:64-7.

45 Mattson MP, Cheng B, Davis D, Bryant K, Lieberburg I, Rydel RE. $\beta$ amyloid peptides destabilize calcium homeostasis and render human 376-89.

46 Baudier J, Cole DR. Phosphorylation of Tau proteins to a state like that in Alzheimer's brain is catalyzed by a calcium/calmodulin-dependent kinase and modulated by phospholipids. f Biological Chemistry 1987;36:17577-83.

47 Karlinsky H, Vaula G, Haines JL, et al. Molecular and prospective phenotypic characterization of a pedigree with familial Alzheimer's disease and a missense mutation in codon 717 of the $\beta$-amyloid precursor protein gene. Neurology 1992;42:1445-53.

48 Lantos PL, Luthert PJ, Hanger D, Anderton BH, Mullan M, Rossor MN. Familial Alzheimer's disease with the amyloid precursor protein 717 
mutation and sporadic Alzheimer's disease have the same cytoskeletal pathology. Neurosci Lett 1992;137:221-4.

49 Ghetti B, Murrell J, Benson MD, Farlow MR. Spectrum of amyloid $\beta$ protein immunoreactivity in hereditary Alzheimer's disease with a guanine to thymine missense change at position 1924 of the APP gene. Brain Res 1992;571:133-9.

50 Kennedy AM, Newman S, McCaddon A, et al. Familial Alzheimer's disease: a pedigree with a missense mutation in the Amyloid precursor protein gene (APP 717 valine to glycine). Brain 1993;116:309-24.

51 Mann DMA, Jones D, Snowden JS, Neary D, Hardy J. Pathological changes in the brain of a patient with familial Alzheimer's disease having a missense mutation at codon 717 in the amyloid precursor protein ing a missense mutation at codon 717

52 Palmer $M$, Collinge J. Human prion diseases. In: $M \quad N$ Rossor, ed. Unusual dementias, 3rd ed. London: Baillière Tindall, 1992:627-51.

53 Collinge J, Poulter M, Davis MB, et al. Presymptomatic detection or exclusion of prion protein gene defects in families with inherited prion diseases. Am f Hum Genet 1991;49:1351-4.

54 Bird TD, Sumi SM, Nemens EJ. Phenotypic heterogeneity in familial Alzheimer's disease: a study of 24 kindreds. Ann Neurol 1989;25:12-21. 55 Schellenberg GD, Bird TD, Wijsman EM, et al. Genetic linkage evidence for a familial Alzheimer's disease locus on chromosome 14. Science 1992;258:668-71.

56 Mullan M, Houlden $\mathrm{H}$, Windelspecht $\mathrm{M}$, et al. A locus for familial earlyonset Alzheimer's disease on the long arm of chromosome 14, proximal to the $a$ 1-antichymotrypsin gene. Nature Genetics 1992;2:340-2.

57 St George Hyslop P, Haines J, Rogaev E, et al. Genetic evidence for a novel familial Alzheimer's disease locus on chromosome 14. Nature Genetics 1992;2:330-4.

58 Van Broekhoven C, Backhovens $H$, Cruts $M$, et al. Mapping of a gene predisposing to early-onset Alzheimer's disease to chromosome 14q24.3 predisposing to early-onset Al

59 Pericak-Vance MA, Yamaoka LH, Haynes CS, et al. Genetic linkage studies in Alzheimer's disease families. Exp Neurol 1988;102:271-9.

\section{Neurological stamp}

\section{John Coakley Lettsom (1744-1815)}

Lettsom, an 18th century Quaker, physician and philanthropist, was one of the central medical figures of the period. His mother, Mary Coakley, bore seven sets of twins. The seventh and last pair were John Coakley Lettsom and his brother Edward-they were the only set of twins to survive.

Lettsom was a phenomenally successful practitioner. It is said that on his long rounds he wore out three pairs of horses each day. In London, he inaugurated a system of dispensaries which enabled poor people to be treated as outpatients. The system was then adopted by many towns throughout the country.

At the age of 28 Lettsom founded the Medical Society of London and in $\mathbf{1 7 8 6}$ he described alcoholic polyneuritis to the Society. As well as the symptoms of neuritis he noted the mental symptoms associated with alcoholism. Lettsom knew nothing of the pathological process of the disease and it is not even clear whether he sensed its location. In spite of the fact that he did not use the term neuritis, he clearly recognised the disorder and its association with the "indulgence of drinking".

During his lifetime a considerable number of verses were written around Lettsom. The most famous lines are those embodying his supposed inclination for bleeding all his patients. "When any sick to me apply, I physics, bleeds and sweats 'em; If after that they choose to die, What's that to me, I. Lettsom".

He was honoured by his country of birth, the British Virgin Islands, in 1973 (Stanley Gibbons 284, Scott 249).

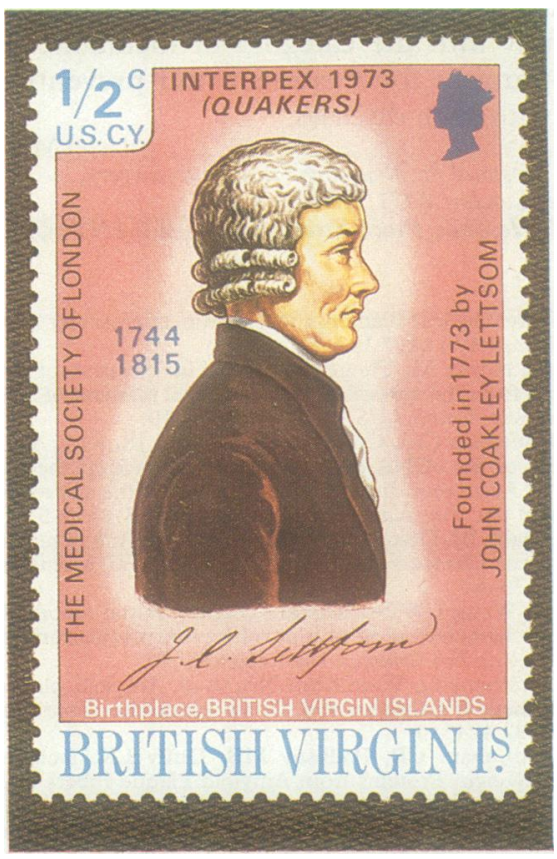

